\title{
A Gender Comparison of Access to Basic Necessities in a South African Township: Application of the Lived Poverty Index
}

\author{
Rachel Nishimwe-Niyimbanira \\ School of Economics, North-West University, Vanderbijlpark, South Africa. \\ E-mail:24720992@nwu.ac.za \\ Tshediso Joseph Sekhampu \\ School of Commerce, Milpark Education, Johannesburg, South Africa. \\ E-mail: joseph.sekhampu@milpark.ac.za \\ Paul-Francois Muzindutsi \\ School of Economics, North-West University, Vanderbijlpark, South Africa. \\ E-mail: 24754293@nwu.ac.za
}

\section{Doi:10.5901/mjss.2014.v5n8p94}

\section{Abstract}

Gender is one of the crucial concepts in the analysis and eradication of poverty. Understanding the link between gender and poverty may assist in developing policies that can have the greatest impact on poverty alleviation. This study used household level data to comparatively analyse the level of access to basic necessities among female and male-headed households in a South African township of Kwakwatsi. Using a simple random sample procedure, 225 households were surveyed in April 2013. A questionnaire was used to collect the relevant information needed in order to assess the level of access to basic necessities. The Lived Poverty Index was used as a measurement of people's capacity to get the basic necessities of life. Findings of this study showed that major challenges in Kwakwatsi Township relate to access to medical treatment, electricity and clean water. Female-headed households reported higher incidences of lack of access to basic necessities than male-headed households. Access to medicines and medical treatment was found to be the biggest challenge to the residents of Kwakwatsi. The results of the study draw attention to a number of challenges relating to access to basic services in South African townships.

Keywords: Lived Poverty Index; poverty; basic necessities; township; South Africa.

\section{Introduction}

Poverty is sometimes linked to various variables such as gender, income, age, marital status, education attainment, employment status, to name few. The link between gender and poverty appears to be complex and very controversial. Females are generally found to be the most deprived and lack behind in many of development indicators. This is alluded to the fact that opportunities, constraints, needs and incentives differ by gender. At a global level, the thinking that female experience a disproportionate and rising share of poverty, rose much attention and became to be known as 'feminisation of poverty' (Chant, 2003; 2006). The proponents of feminization of poverty insist that households headed by female are seen as the poorest of the poor and that concerted efforts should be made in eradicated the associated challenges (Buvinic \& Gupta, 1997). These challenges are more evident in the developing world, where an increased number of females are heading households. A household is described as a group of persons (or one person) whose food provision, shelter and other essentials for living are done in common (Bongaarts, 2001; StatsSA, 2012). The head of the household is the person who is recognized by the other members as such (UN, 1980; StatsSA, 2012). The relationship between household headship and feminisation of poverty originates from the concern that households headed by female constitute a growth proportion of the poor and live in greater poverty than their male counterparts (Bridge, 2001).

Bridge (2001) suggested three perspectives which can explain the concept of feminisation of poverty. Firstly, women's poverty incidence is higher than that for males. Secondly, poverty among women is more severe than among men. On average, poor women are poorer than poor men. Finally, the rates or levels of poverty among women increase with increasing numbers of female headship. This means that an increase in the rate of households headed by females 
implies an increase in the rates and levels of poverty among women. Bridge's (2001) perspectives therefore suggest that females heading households, among other females, present the greatest poverty risks. As a result, the precise nature of the connection between gender and poverty needs a deep understanding and should inform policymaking (Cagatay, 1998). When it comes to female household headship, some may argue that female household's heads may be more independent and have more control over resources than other women who are not household heads. However, it is important to remember that a female head might be the main and only provider, not only for the needs of their dependents, but also for their own needs. In other words, female household's heads tend to have more responsibilities than other females who normally have support from their spouses or partners. In addition, female household's heads tend to face labour market disadvantages and time constraints because of tasks relating to the upkeep of the household and this makes it difficult for them to earn sufficient income (Moghadam, 1998; Fuwa, 2000).

A number of studies have been conducted on poverty and gender. These studies generally conclude that femaleheaded households are poorer than male-headed households (Haddad et al., 1996; Buvinic \& Gupta, 1997; Ray, 2000; Dungumaro, 2008). Studies on poverty and gender are based on various indicators of poverty such as household income and consumption, mean income per adult equivalence, expenditure, access to services and ownership of land and assets (Buvinic \& Gupta, 1997). Buvinic and Gupta (1997) reviewed studies on the relationship between the gender of the household head and poverty and found that in the majority of these studies, female-headed households were overrepresented among the poor. Furthermore, Haddad et al. (1996) found higher incidences of poverty among femaleheaded households as compared to those headed by males in selected developing countries. They conclude that both household features and the process of household formation are the major determinants of the extent of poverty among female-headed households. Quisumbing et al. (1995) analysed the extent of poverty in male and female-headed households in ten developing countries. However, they did not find convincing evidence supporting the difference in poverty levels between male and female-headed households. Female-headed households were found to be more deprived only in two countries (Ghana and rural Bangladesh). Other studies disagree that households headed by female are poorer than those headed by male (Chant, 2006; Aggarwal, 2012). This is also confirmed by Koster (2008) who found that in Rwanda, households headed by female are not the poorest of the poor and argued that referring to these households as poor is tantamount to improper victimisation.

In the South African context, various studies have shown that there is a relationship between gender and poverty (Budlender, 1997; Ray, 2000; Dungumaro, 2008). Most of these studies revealed that households headed by females are relatively underprivileged in terms of assets and income or are significantly over-represented among the poor. However, Mtshali (2002) discovered that in the rural area of KwaZulu-Natal, male-headed households were poorer than femaleheaded households. This is because female-headed households tend to diversify their income-generating activities more than male-headed households. Overall, these studies reveal that the gender of the household head has an impact on the poverty status of a household but there is no general consensus on the difference in poverty levels between male and female-headed households. Hence, more research on this topic is still required, especially in low-income areas such as townships.

The current study analysed how residents of Kwakwatsi Township access basic necessities, such as water, medicines, electricity, food, cash income and fuel for cooking. The Lived Poverty Index (LPI) was used as a measurement that assesses whether people have the basic necessities (resources) necessary for well-being in order to escape poverty. The study aims to identify the level of access to basic necessities of inhabitants of Kwakwatsi and compare the access to basic necessities between male and female-headed households. The rest of the article is organised as follows: Section 2 is an overview of the research methodology used; Section 3 presents and discuss the results of the study; and Section 5 concludes the article.

\section{The research methodology}

\subsection{Survey area}

The geographical area covered by the study entails the area called Kwakwatsi. It is a former black residential township located approximately $180 \mathrm{~km}$ south of Johannesburg and $280 \mathrm{~km}$ north of Bloemfontein in the Free State province of South Africa. The area is part of the Ngwathe Local Municipality, with its head office in Parys (Ngwathe Municipality, 2007). The area could be classified as a semi-rural township, with little economic activity. The nearest industrial town of Sasolburg is $70 \mathrm{~km}$ away. The estimated population size of Kwakwatsi was 15095 in 2009 (Ngwathe Municipality, 2009). In South Africa, the term township and location usually refers to the often underdeveloped urban living areas that, from the late 19th century until the end of apartheid, were reserved for non-whites, principally Black and Coloureds 
(Ramnarain, 2013). They were usually built on the periphery of towns and cities (Ramnarain, 2013). In the townships, households are caught in poverty trap from which they are unlikely to escape without government help. A large number of the population lives in these semi-urban areas, which continue to grow at a rapid rate.

\subsection{Instrument and measures}

A survey questionnaire was used to gather the necessary data for this study. The questionnaire was divided into three sections. The first two parts of the questionnaire were developed based on literature, while the third section was adopted from Mattes at al. (2002). The first two parts covered different aspects of households' socio-economic and demographic characteristics, while the third section contains questions about the "lived poverty index" (LPI) which measure the level of access to basic necessities by a household. The LPI measures people's capacity to get the basic necessities of life. More explicitly, respondents were asked "over the past year, how often, if ever, have you or your family gone without: enough food to eat, enough clean water for home use, medicines or medical treatment, electricity in your home, enough fuel to cook your food, and/ or a cash income? The response options employed by Mattes et al. (2002) and Dulani et al. (2013) range from 0 (never: no lived poverty) to 4 (always: which reflects a regular absence of all basic necessities). LPI was constructed from these six question items about access to basic necessities with the use of Principal Component Analysis (PCA). Principal component analysis (PCA) is a procedure for reducing the dimensionality of a data set consisting of a certain redundancy in variables, while retaining as much as possible of the variation that may be present in the data set (Jolliffe, 2002). Thus, PCA is a procedure of reducing variables into a small number of components accounting for maximum variance in a set of observed variables (Hatcher, 1994). This means that PCA groups related variables into themes known as components.

This study followed others which used PCA (Mattes et al., 2002; Mattes, 2008; Davids 2010a; 2010b; Dulani et al., 2013) and found that all six questions were loaded into one component named LPI. In the context of this study, PCA was used to check if all six items could be loaded into one component of LPI. This was done with the use of Kaiser's criterion and scree plot test. Kaiser's criterion states that only factors with an eigenvalue of 1.00 or greater are retained for analysis (Pallant, 2013:191). Cronbach's Alpha test was used to test the reliability of the questionnaire, while Bartlett's test for sphericity and Kaiser-Meyer-Olkin (KMO) were performed to measure the sampling adequacy and to determine the meaningfulness of performing principal component analysis. Principal component analysis is advisable only if the variables involved are sufficiently correlated. George and Mallery (2003) and Pallant (2013) stipulated that a Cronbach's Alpha value of greater than 0.6 means that the component is reliable. The sample is adequate when the KMO is greater or equal to 0.6, while the performance of principal component would be appropriate if Bartlett's Test of Sphericity is significant $(p<0.05)$ (Pallant, 2013).

\section{Findings and Discussion}

\subsection{The description of the participants}

In the analysis of the observations, the sample was disaggregated into two sub-samples: female-headed households and male-headed households and their results are compared. The average household size was calculated to be 4.4 persons per household. The description based on the gender of the household showed that average household size for maleheaded households is slightly higher (4.5) than those headed by females (about 4). Females only account for 30.7 percent of household heads. The unemployment rate among the household heads was higher among males (27.6\%) compared to females (26.1\%). The total number of employed people within a household was less in female-headed households (1.7) compare to those headed by males (2.2). The average income of the household head (for the whole sample) was calculated at R2 061 per month, but the average income of females heading households (R1551) is lower than that of males (R2287). Apart from household head income, the average total household income in female-headed households (R3084) was lower than those headed by males (R4420).

\subsection{The incidence of poverty in Kwakwatsi}

Using PCA, it was possible to retain a single un-rotated factor with an Eigenvalue of 2.8 that explains 48.12 percent of the common variance to all six of the items. The KMO of 0.757 was obtained and is considered good (Kaiser, 1974). Bartlett's test of sphericity (chi-square equal to $474.941, \mathrm{p}=0.000<0.01$ ) indicated that the correlation between items was sufficiently large for PCA. The LPI was found to be a reliable measure as its Cronbach's alpha (0.72) was above 0.6 
standard cut-off point (Pallant, 2013). This implies that all variables can be classified in 1 component, shown by the component matrix in Table 1. The scree plot also confirmed the use of one component which means that LPI is described by all six items.

Table 1: Component matrix: reasons why people are poor

\begin{tabular}{l|c}
\hline & Component 1 \\
\hline Enough clean water for home use & 0.863 \\
Electricity in their home & 0.855 \\
Enough fuel to cook food & 0.817 \\
A cash income & 0.590 \\
Enough food to eat & 0.539 \\
Medicines or medical treatment & 0.323 \\
\hline
\end{tabular}

\subsection{Access to basic necessities - overall sample}

Table 2 shows the level of access to basic necessities of the sampled population. In general, access to medicines and medical treatment appear to be the biggest challenge to the whole township of Kwakwatsi. About 70.2 percent of the sample population reported that they have experienced a shortage of medicines or medical treatment once/twice or several times. Access to medical treatment seems to differ, depending on the survey area, as a study by Dulani et al. (2013) reported that 60 percent of South Africans have never experienced a shortage of medicines or medical treatment. This is largely attributed to the national government's strategy of providing free primary health care to all citizens.

Table 2: Level of access to basic necessities of the sampled population (\%)

\begin{tabular}{l|c|c|c|c|c}
\hline & Never & Once or twice & Several times & Many times & Always \\
\hline Enough food to eat & 88.0 & 6.2 & 3.6 & 1.3 & 0.9 \\
Enough clean water for home use & 5.3 & 68.9 & 20.0 & 4.9 & 0.9 \\
Medicines or medical treatment & 11.1 & 24.4 & 45.8 & 14.2 & 4.4 \\
Electricity in your home & 4.4 & 66.2 & 22.7 & 6.2 & 0.4 \\
Fuel for cooking & 8.0 & 70.7 & 16.0 & 4.9 & 0.4 \\
A cash income & 77.8 & 9.8 & 4.9 & 4.4 & 3.1 \\
\hline
\end{tabular}

Electricity is another problem for the community of Kwakwatsi (only 4.4 percent of the sampled population reported to have never experienced any shortage of electricity over the year preceding the interview). About 88.9 percent have experienced a lack of electricity once/twice or several times, while 6.2 percent experienced it many times during the past year. The problem of access to electricity was also exacerbated by erratic power cuts attributed to grid problems by the local municipality. Regarding clean water, 68.9 percent of the participants reported that they have experienced a lack of clean water once or twice, while 20 percent experienced a shortage several times in the last year. Regarding fuel for cooking, 70.7 percent reported that they have experienced a shortage just once or twice in the last year. A report by Dulani et al. (2013) revealed that approximately 30 percent of South Africans experienced a shortage of fuel for cooking at least once. As for cash income, it appears to be a minor problem as the majority of the participants (77.8\%) reported to have never experienced any shortage. About 44 percent of South Africans were found to have experienced a shortage of cash income during the past year, while 20 percent have experienced it many times or always (Dulani et al., 2013). It appears that this cash income is used primarily to secure food, because 88.0 percent of the sampled population have never gone without food over the twelve months preceding the study.

\subsection{Access to basic necessities by gender of the household's head}

This subsection explores the way households headed by females access basic necessities, compared to those headed by males. Results, in Table 3, are disaggregated by gender of the head and how they responded to each question.

Food: Table 3 shows that male-headed households are likely to get enough food compared to those headed by females. About 89.74 percent of male-headed households have never gone without enough food to eat during the last twelve months, compared to 84.06 percent of those headed by females. If one does a coarse interpretation (combination of 
several times, many times and always) of these results, approximately 8.7 percent of households headed by females experienced hunger compared to 4.5 percent of male-headed households. However, hunger does not seem to be a severe problem among female-headed households, because there is no female-headed household which has always experienced a shortage of food. These findings appear to be in line with the results of Jacobs (2010), who found that male-headed households are more likely to never experience adult hunger than female-headed households. His study concluded that in the Free State Province, 87.72 percent of male-headed households reported to have never experienced hunger, compared to 83.28 percent of female-headed households. In addition, StatsSA (2010) found that African females were consistently and distinctively more likely to experience vulnerability to hunger than their male counterparts. Moreover, a significant difference in food security among male and female-headed households was determined by Modirwa and Oladele (2012) where they found that male-headed households were more food secured than femaleheaded households in Eden District Municipality of the Western Cape, South Africa.

Table 3: Access to basic services by gender (\%)

\begin{tabular}{l|c|c|c|c|c|c|c|c|c|c}
\hline & \multicolumn{2}{|c|}{ Never } & \multicolumn{2}{c|}{ Once or twice } & \multicolumn{2}{c|}{ Several times } & \multicolumn{2}{c|}{ Many times } & \multicolumn{2}{c}{ Always } \\
\cline { 2 - 11 } & $\mathrm{MHH}$ & $\mathrm{FHH}$ & $\mathrm{MHH}$ & $\mathrm{FHH}$ & $\mathrm{MHH}$ & $\mathrm{FHH}$ & $\mathrm{MHH}$ & $\mathrm{FHH}$ & $\mathrm{MHH}$ & $\mathrm{FHH}$ \\
\hline Food to eat & 89.74 & 84.00 & 5.7 & 7.25 & 1.28 & 8.70 & 1.92 & 0.00 & 1.28 & 0.00 \\
Clean water & 5.13 & 5.80 & 67.95 & 71.01 & 19.87 & 20.29 & 6.41 & 1.45 & 0.64 & 1.45 \\
Medicines & 9.62 & 14.49 & 28.85 & 14.49 & 44.23 & 49.28 & 13.46 & 15.94 & 3.85 & 5.80 \\
Electricity & 5.13 & 2.90 & 64.10 & 71.01 & 22.44 & 23.19 & 8.33 & 1.45 & 0.00 & 1.45 \\
Cooking fuel & 8.97 & 5.80 & 66.03 & 81.16 & 19.23 & 8.70 & 5.13 & 4.35 & 0.64 & 0.00 \\
Cash income & 82.05 & 68.12 & 8.97 & 11.59 & 1.28 & 13.04 & 4.49 & 4.35 & 3.21 & 2.90 \\
\hline
\end{tabular}

$\mathrm{MHH}=$ male-headed households and $\mathrm{FHH}=$ female-headed households

Cash income: The reason behind the better position in securing enough food in male-headed households might be the better disposition of cash income. Approximately, 82.05 percent of the male-headed households reported that they have never gone without cash income in the past year, while 68.12 percent was recorded for female-headed households. The average income per month of a female household's head (R1551.01) appeared to be lower than that of a male household head (R2287.05). Apart from income of the household head, it was found that the average total household income in female-headed households (R3084.347) is lower than that of male-headed households (R4420.128). StatsSA (2012) revealed that in 2011, on average, a female earned just more than half the annual income of males. At the household level, StatsSA (2010) further reported that female-headed households are much more likely to have low incomes than those headed by males. The interpretation of the combination of the last three response options (several times, many times and always) suggests that 8.98 percent of male-headed households experienced a shortage of cash income, compared to 20.29 percent of female-headed households. Conversely, 3.21 percent of male-headed households always experienced a cash income shortage, compared to those headed by females (2.90\%), but the difference between these households is too small $(0.31 \%)$.

Electricity: Electricity is one of the most important factors in social and economic development. It takes a large share of disposable income amongst other expenses of the household. Lloyd \& Cowan (2005) pointed out that many low-income South African households which have electricity use it mostly for low-power consuming items such as communication devices and for lighting the household. Female-headed households appear to be less likely to secure electricity for their homes compared to those headed by males. However, overall affordability of electricity in both households is still at a low level. About 5.13 percent of male-headed households have never gone without electricity in their homes, compared to 2.9 percent of female-headed households. Approximately, 71 percent of female-headed households have gone without electricity at least once, compared to 64 percent of male-headed households. More households headed by females seem to be in a serious position of lacking electricity. In dire cases, 1.45 percent of female-headed households always went without electricity in their homes (this can be considered that they did not have it at all), while there was no report of not having electricity among the male-headed households. StatsSA (2010) found that female-headed households were consistently less likely to be connected to the mains source of electricity than those headed by males for the period of eight years (from 2002 to 2009).

Fuel for cooking: In South Africa, electricity is not the first option for cooking as many people still choose other sources of energy such as paraffin, wood and coal, especially in rural areas (Lloyd \& Cowan, 2005). Approximately, 8.97 percent 
of male-headed households have never gone without fuel for cooking, while female-headed household recorded 5.8 percent. Even though the number of households headed by males which have never gone without fuel for cooking is higher than those headed by females, when the first two categories are combined (never and gone once or twice without fuel for cooking) female-headed households (87\%) appear to have better access to fuel for cooking than those headed by males (75\%). There are more male-headed households that experienced a lack of fuel for cooking several times $(19.23 \%)$, many times $(5.13 \%)$ and always (0.64\%), compared to those headed by females (which account for 8.70 percent, 4.35 percent and zero percent, respectively). Bhorat et al. (2009) found that 73 percent (year 2007) and about 70 percent (year 2008) of male-headed households used electricity for cooking, compared to 60 percent and 68 percent of households headed by female, respectively. This means that a greater percentage of female-headed households use alternative sources of energy to cook compared to those headed by males. These alternative sources of energy to electricity are associated with numerous health, environmental and social problems and a larger number of femaleheaded households use them compared to those headed by males.

Medicines or medical treatment: The South African government has developed primary health care centres with universal access and Kwakwatsi Township has one primary healthcare facility on the outskirts of the area. Regardless of the high numbers of primary health care centres that have been constructed, Bradshaw and Steyn (2001) concluded that many lacked adequate staff and facilities to provide proper care to outpatients. Most clinics in townships are faced with very large numbers of additional patients, as large hospitals tend to be long distances from areas of residence. These limitations on primary health care are a challenge for the inhabitants of Kwakwatsi as the hospital serving the area is in the town of Kroonstad, some $80 \mathrm{~km}$ away from the township. Female-headed households were the ones who were identified as having a higher percentage (5.8\%) in the critical condition of always experiencing a lack of medicines or medical treatment than those headed by males (3.85\%). In addition to this, 19.94 percent of female-headed households reported that they have gone many times without medicines or medical treatment, compared to 13.46 percent of those headed by a male. Yet the combination of the first two categories (never and once or twice) shows that male-headed households had better access to medicines and medical treatment in the last twelve months, with 38.47 percent compared to 28.98 percent of those headed by females. According to StatsSA (2010), males are generally more likely to have membership of medical aid plans than females, which of course increase their access to medicines and medical treatment.

Clean water: Water is said to be the essence of life and a major natural resource. Being deprived of clean water might be derived from being "income poor" due to lack of clean water. Even in regions where water supply is adequate and reliable, people's income may be too low to afford the cost of using clean water, which would compel them to use inadequate and unreliable sources of water supply (Lawrence et al., 2002). The fact that male-headed households are more cash income secure than those headed by females does not mean that they are not more water poor than femaleheaded households. This is justified by how preferences and priorities between these two households may differ. About 5.81 percent of female-headed households have never experienced lack of enough clean water for home use, while those headed by males record 5.17 percent. About, 71.01 percent of female-headed households have experienced a shortage of clean water once or twice over the year prior to the survey, compared to 67.95 percent of male-headed households. Yet a comparison of the two last categories of answers (many times and always) shows that male-headed households $(7.05 \%)$ are more likely to go without clean water than female-headed households (2.9\%). However, more female-headed households (1.45\%) compared to those headed by males $(0.64 \%)$ have always gone without enough clean water for home use over the year prior to the survey. This finding is similar to that of StatsSA (2010), which reported that female-headed households are significantly more likely to have access to water than those headed by males.

\section{Conclusion and Recommendations}

The aim of the study reported here was to provide a gender analysis of access to basic necessities in a South African township. Using a survey questionnaire, data was collected from a random sample of 225 households in the township of Kwakwatsi. The Lived Poverty Index (LPI) was used as a measurement to assess whether the participants have access to the basic necessities (resources) necessary for well-being in order to escape poverty. This is because poverty has numerous dimensions that affect people's lives and should viewed from various facets. South Africa, like the rest of SubSaharan African, is faced with high levels of inequality in society, where a large proportion of the population does not have full access to basic necessities. Without access to quality health care and education and income-earning 
opportunities, a large majority with inadequate income appears to face a day-to-day struggle to barely survive. Access to basic necessities such as medicines or medical treatment, water, electricity and fuel for cooking have an effect on the quality of life for the residents of Kwakwatsi. In general, access to medicines and medical treatment was found to be the biggest challenge to the residents of Kwakwatsi, and this might be due to the fact that they share only one primary healthcare facility. The residents struggle to have access to electricity, fuel for cooking, and clean water for home use, subject to households' income constraints. A greater proportion of female-headed households in the area reported to have experienced shortages of basic necessities, compared to male-headed households.

Findings of this study draw attention to the desperate situation relating to lack of access to basic services in many of South Africa's townships. Poverty alleviation cannot focus only on the simple approach of increasing income, but should be understood as a multidimensional problem. The concept of poverty should not only include income or consumption poverty but also deprivation of basic necessities and human poverty. Policy makers need to develop strategies addressing the lack of medicines or medical treatment, electricity, fuel for cooking, clean water and cash income in low-income areas such as townships. More specifically, South African policy makers should find ways of improving access to medicines or medical treatment; especially in low income areas. This can be achieved by providing funds and adequate infrastructure to some public primary health care centres in townships. To improve the conditions of female household's heads, government should support and create a good environment for co-operative organisations for women. Through this, females from low income areas can be encouraged to establish employment associations where they can be reached easily by sponsors and relevant government departments. This will make their access to resources, such as credit, adequate training and knowledge, easier. Further studies could be undertaken to investigate how households' demographic (beyond the gender of the household head) and socio-economic aspects affect the access to basic necessities in Kwakwatsi Township.

\section{References}

Aggarwal, V.S. 2012. Female-headed households and feminisation of Poverty. Research journal of social science and management, 04(02):57-62.

Bhorat, H., van der Westhuizen, C. \& Cassim, A. 2009. Findings from NIDS 2008: Access to household services and assets. NIDS Discussion Paper No. 4, SALDRU.

Bongaarts, J. 2001. Household size and composition in the developing world in the 1990s. Population studies: A Journal of Demography, 55(3):263-279.

Bradshaw, D. \& Steyn K. eds. 2001. Poverty and chronic diseases in South Africa. Technical report 2001, MRC South Africa. http://www.mrc.co.za/bod/povertyfinal.pdf Date of access 14 August 2013.

Bridge. 2001. Briefing paper on the "feminisation of Poverty" prepared for the Swedish International Development Cooperation Agency (SIDA). BRIDGE Report No.59, Brighton: Institute of Development Studies, University of Sussex.

Budlender, D. 1997. The Women's Budget. Agenda, 33:37-42.

Buvinic, M. \& Gupta G.R. 1997. Female-Headed Households and Female-Maintained Families: Are They Worth Targeting to Reduce Poverty in Developing Countries? Economic Development and Cultural Change, 45(2):259-280.

Cagatey, N. 1998. Gender and poverty. UNDP social development and poverty elimination division, working paper No. 5.

Chant, S. 2003. Female household headship and the feminisation of Poverty: Facts, fictions and forward strategies. New Working Paper Series, Issue 9, London: London School of Economics. http://personal.Ise.ac.uk/chant/chantpublications/blar_288.pdf Date of access 28 May 2013.

Chant, S. 2006. Revisiting the feminisation of poverty and the UNDP Gender Indices: What case for a gendered poverty index? Gender Institute Working Paper Series, 18, London: London School of Economics.

Davids, Y.D. 2010a. Explaining poverty: a comparison between perceptions and conditions of poverty in South Africa. Stellenbosch University (Thesis-PhD).

Davids, Y.D. 2010b. Impact of perceptions of poverty on the well-being of South Africans. Human Sciences Research Council. http://www.hsrc.ac.za Date of access 20 August 2013.

Dulani, B., Mattes, R. \& Logan, C. 2013. After a decade of growth in Africa, little change in poverty at the grassroots. www.afrobarometer.org Date of access 04 October 2013.

Dungumaro, E.W. 2008. Gender differentials in household structure and socioeconomic characteristics in South Africa. Journal of Comparative Family Studies, 39(4):429-451.

Fuwa, N. 2000. A note on the analysis of female-headed household in developing countries. Munich Personal RePEc Archive, 54:25138.

George, D., \& Mallery, P. 2003. SPSS for windows step by step: a simple guide and reference. $4^{\text {th }}$ ed. Boston: Allyn \& Bacon.

Haddad, L., Pena C., Nishida C., Quisumbing A. \& Slack, A. 1996. Food security and nutrition implications of intra-household Bias: a review of literature. FCND Discussion Paper 19. Washington, DC: IFPRI (International Food Policy Research Institute).

Hatcher, L. 1994. A step-by-step approach to using SAS factor analysis and structural equation modelling. Cary, NC: SAS Institute. Inc. 
Jolliffe, I.T. 2002. Principal component analysis. $2^{\text {nd }}$ ed. New York: Springer.

Kaiser, H.F. 1974. An index of factorial simplicity. Psychometrika, 39:31-36.

Koster, M. 2008. Linking Poverty and Household in Post-Genocide Rwanda. Wageningen, Wageningen University. (Thesis - PhD).

Jacobs, P.T. 2010. Household food insecurity, rapid food price inflation and the economic downturn. Paper presented at the Joint $3 r d$ African Association of Agricultural Economists (AAAE) and 48th Agricultural Economists Association of South Africa (AEASA) Conference, Cape Town, South Africa, September 19-23.

Lawrence, P., Meigh, J. \& Sullivan, C. 2002. The Water Poverty Index: an international comparison. Keele Economics research papers. www.keele.ac.uk/depts/ec/kerp Date of access 10 September 2013.

Lloyd, P, and Cowan, B. 2005. Improving access to electricity: lessons from Khayelitsha. Conference on domestic use of energy 2005. http://active.cput.ac.za/energy/past_papers/DUE/2005/PDF/23\%20D3\%203\%20-\%20P\%20Lloyd.pdf Date of access 20 September 2013.

Mattes, R. 2008. The material and political bases of lived poverty in Africa: Insights from the Afrobarometer. (In Møller et al. eds. Barometers of Quality of Life around the Globe. Springer. p.161-185).

Mattes, R., Bratton, M. \& Davids, Y.D. 2002. Poverty, survival and democracy in Southern Africa. Centre for Social Science Research, University of Cape Town, CSSR Working Paper No.27.

Modirwa, S. \& Oladele, O.I. 2012. Food security among male and female-headed households in Eden District Municipality of the Western Cape, South Africa. Journal Human Ecology, 37(1):29-35.

Moghadam, V. 1998. The feminization of poverty in international perspective. Brown Journal of World Affairs, 5(2):225-250.

Msthali, S.M. 2002. Household livelihood security in rural KwaZulu-Natal South Africa. Wageningen, Wageningen University. (Thesis $\mathrm{PhD}$ ).

Ngwathe Municipality. 2007. Integrated development plan 2007-2012. Parys: Ngwathe Municipality.

Ngwathe Municipality. 2009. Integrated Development Plan Review 2009-2010. Parys: Ngwathe Municipality.

Pallant, J. 2013. A step by step guide to data analysis using IBM SPSS: survival manual. $5^{\text {th }}$ ed. Maidenhead: Mc Graw Hill.

Quisumbing, A.R., Haddad, L., \& Pena, C. 1995. Gender and poverty: new evidence from 10 Developing Countries. FCND Discussion Paper 9. Washington, DC: International Food Policy Research Institute.

Ramnarain, D. U. 2013. The Achievement Goal Orientation of Disadvantaged Black Physical Sciences Students from South Africa. Mediterranean Journal of Social Sciences, 3(3):152-157.

Ray, R. 2000. Poverty and expenditure patterns of households in Pakistan and South Africa: a comparative study. Journal of International Development, 12(2):241-256.

StatSA. 2010. Social profile of South Africa, 2002-2009. Pretoria: Government printer.

StatSA. 2012. Census 2011. Statistical release (Revised) P0301.4. Pretoria: Government printer.

UN (United Nations). 1980. Principles and recommendations for population and housing censuses. Statistical Papers Series M. No. 67. New York: UN. 